\title{
LTC 1073 Vacuum Blasting (Concrete) Human Factors Assessment - Baseline (Summary)
}

\section{Topical Report July 31, 1997}

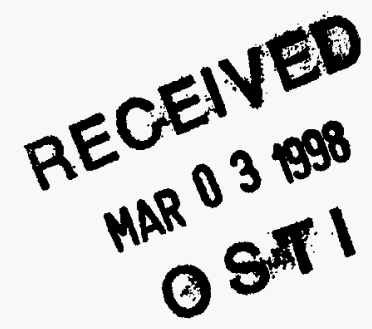

Work Performed Under Contract No.: DE-FC21-95MC32260

For

U.S. Department of Energy

Office of Environmental Management Office of Technology Development

1000 Independence Avenue

Washington, DC 20585

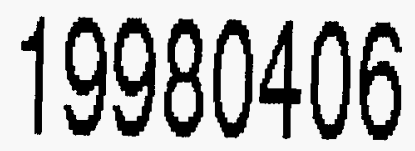

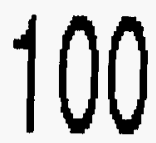

By

Operating Engineers National Hazmat Program

250 Airport Circle

Beaver, West Virginia 25813
U.S. Department of Energy

Office of Fossil Energy

Federal Energy Technology Center

Morgantown Site

P.O. Box 880

Morgantown, West Virginia 26507-0880

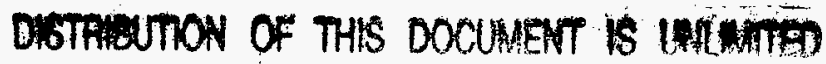
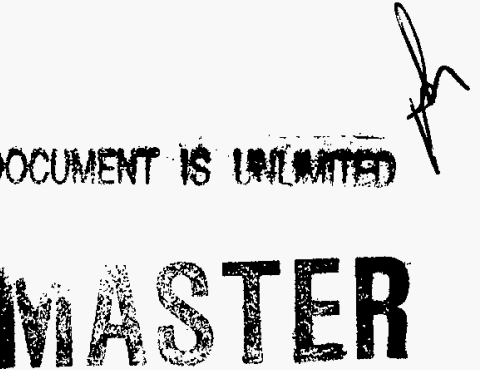


\section{Disclaimer}

This report was prepared as an account of work sponsored by an agency of the United States Government. Neither the United States Government nor any agency thereof, nor any of their employees, makes any warranty, express or implied, or assumes any legal liability or responsibility for the accuracy, completeness, or usefulness of any information, apparatus, product, or process disclosed, or represents that its use would not infringe privately owned rights. Reference herein to any specific commercial product, process, or service by trade name, trademark, manufacturer, or otherwise does not necessarily constitute or imply its endorsement, recommendation, or favoring by the United States Government or any agency thereof. The views and opinions of authors expressed herein do not necessarily state or reflect those of the United States Government or any agency thereof. 


\section{LTC 1073 VACUUM BLASTING (CONCRETE) \\ HUMAN FACTORS ASSESSMENT - BASELINE}

\section{SECTION 1 - SUMMARY}

\section{Technology Description}

The LTC 1073 Vacuum Blasting Machine uses a high-capacity, direct-pressure blasting system incorporating a continuous feed for the blast media. The blast media cleans the surface within the contained brush area of the blast head. A vacuum system removes dust and debris from the surfaces as it is blasted. After cleaning the surface, the abrasive, together with the rust or coating that was removed from the surface, is vacuumed into the machine through the suction hose. The dust separator contains angled steel collision pads, working with the force of gravity, to allow any reusable abrasive to fall back into the pressure vessel. The filters are manually back-flushed to prevent clogging. After back-flushing, dust is dumped from the dust chamber into the dust collection bag or drum by operation of the bellows valve.

\section{Key Results}

The safety and health evaluation during the testing demonstration focused on dust and noise exposure. Dust exposure was found to be minimal, but noise exposure was potentially significant. Further testing for each of these exposures is recommended because the outdoor environment where the testing demonstration took place may cause the results to be inapplicable to indoor settings. It is feasible that the dust and noise levels will be higher in an enclosed operating environment. Other safety and health issues found were ergonomics, heat stress, tripping hazards, lockout/tagout, and arm-hand vibration.

\section{SECTION 2 - HEALTH AND SAFETY EVALUATION}

\section{General Safety and Health Concerns}

Safety and health issues of concern with the LTC vacuum blasting machine included tripping hazards, rotating machinery, lockout/tagout, heat stress, ergonomics, arm-hand vibration, noise, dust, and communication.

\section{Industrial Hygiene Monitoring}

During the testing demonstration, sampling was conducted for dust and noise. In addition, the wet-bulb globe temperature was monitored and observational evaluation was conducted for ergonomics and arm-hand vibration and whole-body vibration.

Ergonomically there is potential for muscle/back stress and/or injury to the knees. Of particular concern was the manual operation of the blasting head. This not only increases back stress/injury but also causes an increase in exposure to the contaminant.

Heat stress was monitored using wet-bulb globe measurements and worker physiological measurements such as blood pressure, pulse, and temperature. Work/rest regimen recommendations were made in accordance with ACGIH recommendations. 
Personal air sampling was conducted on the equipment operator and the assistant. personal dust sampling results were below allowable levels. Noise monitoring recorded a dose of $354.16 \%$ or an 8-hour TWA of $99.1 \mathrm{dBA}$, and a dose of $337.6 \%$ or an 8-hour TWA of $98.7 \mathrm{dBA}$ for the Operators Number 1 and Number 2 respectively. This exceeds the OSHA action level of $85 \mathrm{dBA}$ and the permissible exposure level of $90 \mathrm{dBA}$ for the amount of time sampled. A hearing conservation program may be necessary for anyone working with or around this equipment.

\section{Human Factors Interface}

The technology was evaluated for operator interface with Anti-C PPE including a full face air-purifying respirator. The only difficulties the operators had while wearing the PPE was some visibility problems due to the full face respirator and some loss of tactile sensation and dexterity during maintenance activities. There was an increase in heat stress associated with the protective ensemble.

\section{SECTION 3 - TECHNOLOGY APPLICABILITY}

The technology did not deposit much visible dust into the atmosphere, and air monitoring did not evidence an excessive dust level; however, the windy outdoor test environment was not representative of an enclosed work environment. There was some larger debris left on the surface at the sides of the scabbling head.

The vacuum blaster will need to be torn down to decontaminate. This will not necessarily guarantee that decontamination for alpha will be complete. It will be difficult to survey for alpha contamination due to all of the small spaces in the equipment which are hard to reach with a probe.

\section{SECTION 4 - REGULATORY/POLICY ISSUES}

The site safety and health personnel where the LTC vacuum blasting technology is being used need to be concerned with safety and health regulations applicable to the issues discussed above. Regulations that will apply may include but not be limited to the following areas: housekeeping, machine guarding, lockout/tagout, ionizing radiation, toxic and hazardous substances, noise, respiratory protection, PPE, HAZCOM, and HAZWOPER.

\section{SECTION 5 - OPERATIONAL CONSIDERATIONS \& RECOMMENDATIONS}

Recommendations for improved worker safety and health include good housekeeping, ergonomic training and awareness, a system to increase operator visibility in the front of the equipment, assuring proper vacuum adjustment for adequate air flow, and engineering. administrative, and/or hearing protection be used for compliance with the OSHA noise standard.

Due to the windy outdoor testing conditions, it is recommended that the noise and dust monitoring be conducted while the technology is in use in an enclosed environment. Since Level $A$ or Level B PPE may be required for contaminants other than alpha radiation, it is recommended that the human factors interface for these levels of protection be conducted.

Research supported by the U.S. Department of Energy's Federal Energy Technology Center, under cooperative agreement DE-FC21-95MC32260 with the Operating Engineers National HAZMAT Program, 250 Airport Circle, Beaver, WW 25813, phone 304-253-8674, fax 304-253-7758. This report was prepared with the support of the US DOE; however, any opinions, findings, conclusions, or recommendations expressed herein are those of the author(s) and do not necessarily reflect the views of the DOE. 
M98002032

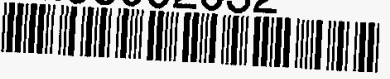

Report Number (14) DOE/mc/32260--5827

Jubl. Date (11) 19970731

Sponsor Code (18) DOE/EM, XF

$J C$ Category (19) $4 C-2000, D O E / E R$

DOE 